\title{
Clinical and Laboratory Findings in Children with Influenza Infections
}

\section{İnfluenza Enfeksiyonu Olan Çocuklarda Klinik ve Laboratuvar Bulguları}

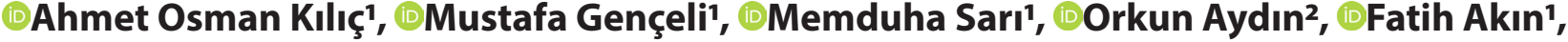 \\ Abdullah Yazar', @Özge Metin Akcan', @Şükrü Nail Güner', @Sevgi Pekcan', \\ ๑Hüseyin Çaksen', @ismail Reisli'
}

\begin{abstract}
${ }^{1}$ Necmettin Erbakan University, Meram Medical Faculty, Department of Pediatrics, Konya, Turkey
\end{abstract}
${ }^{2}$ Hacettepe University, School of Medicine, Department of Pediatrics, Ankara, Turkey

\begin{abstract}
Objective: We aimed to show the clinical characteristics of children with influenza infection and the relationship between influenza infections and hemogram parameters, neutrophil/ lymphocyte ratio, platelet/lymphocyte ratio, neutrophil/ monocyte ratio, and mean platelet volume.

Material and Method: The data of patients who applied to Necmettin Erbakan University Meram Medical Faculty Department of Pediatrics outpatient clinics and had positive rapid influenza test were scanned through the hospital information system.

Results: The median age and neutrophil value in the influenza A group were significantly lower than in the influenza B group $(p=0.002, p=0.008)$. The median MPV and monocyte value in the influenza A group were significantly higher than in influenza $B(p<0.00, p=0.005)$. The mean WBC count was found to be significantly higher in hospitalized patients compared to outpatients $(p=0.039)$. There were no significant difference between the groups in terms of NLR, PLR, NMR. Bacteremia was detected significantly more in hospitalized patients compared to outpatients. Underlying chronic diseases were significantly lower in outpatients than in inpatients $(p<0.001)$.
\end{abstract}

Conclusion: There were no difference in the severity of clinical severity between infleunza $A$ and $B$ subgroups and no significant difference was found in terms of hemogram parameters.

Keywords: Influenza A, Influenza B, hemogram parameters, Neutrophil/lymphocyte ratio, hospitalization, children
Öz

Amaç: Bu çalışmada influenza enfeksiyonu olan çocukların klinik özelliklerini ve nötrofil/lenfosit oranı, trombosit/lenfosit oranı, nötrofil/monosit, ortalama trombosit hacmi gibi laboratuvar bulgularını göstermeyi amaçladık.

Gereç ve Yöntem: Necmettin Erbakan Üniversitesi Meram Tıp Fakültesi Çocuk Sağlığı ve Hastalıkları Anabilim Dalı polikliniklerine başvuran ve hızlı influenza testi pozitif çıkan hastaların verileri hastane bilgi sistemi üzerinden tarandı.

Bulgular: İnfluenza A grubunda ortanca yaş ve nötrofil değeri influenza $B$ grubuna göre anlamlı derecede düşüktü $(p=0,002$, $p=0,008)$. Influenza A grubunda ortanca MPV ve monosit değeri influenza B'ye göre anlamlı derecede yüksekti ( $p<0,00, p=0,005)$. Hastanede yatan hastalarda ortalama WBC sayısı ayaktan hastalara göre anlamlı derecede yüksek bulundu. ( $p=0,039)$. NLR, PLR, NMR açısından gruplar arasında anlamlı fark yoktu. Hastanede yatan hastalarda ayaktan hastalara göre anlamlı derecede daha fazla bakteriyemi saptandı. Altta yatan kronik hastalıklar ayaktan hastalarda yatan hastalara göre anlamlı derecede düşüktü $(p<0,001)$.

Sonuç: Influenza A ve B alt grupları arasında klinik şiddet şiddeti açısından fark bulunmadı ve hemogram parametreleri açısından anlamlı fark bulunmadı.

Anahtar Kelimeler: Influenza A, İnfluenza B, kan sayımı parametreleri, Nötrofil/lenfosit oranı, hastaneye yatış, çocuklar

Corresponding (illetişim): Ahmet Osman Kılıç, Necmettin Erbakan University, Meram Medical Faculty, Department of Pediatrics, 42080, Meram, Konya, Turkey

E-mail (E-posta): drahmetosmankilic@gmail.com

Received (Geliş Tarihi): 23.09.2021 Accepted (Kabul Tarihi): 10.11.2021 


\section{INTRODUCTION}

Influenza virus infections cause high rates of morbidity and mortality all over the world. It causes infections in more than 1,000,000,000 people, serious illness in five million people, deaths of 250 to 500 thousand people each year. ${ }^{[1]}$ It has been reported that influenza viruses infect $20-50 \%$ of children during the periods of pandemic. ${ }^{[2]}$ It is estimated that the number of hospitalizations due to influenza in children under five years of age worldwide is more than 870,000 per year. ${ }^{[3]}$

Most influenza infections are self-limiting. However, the disease may lead to clinical manifestations including upper and lower respiratory tract infection, acute respiratory distress syndrome (ARDS) myocarditis, myositis, febrile convulsion, central nervous system infections and death. ${ }^{[2-6]}$ The disease can cause fatal complications even in healthy children without any underlying disease. It has been reported that mortality and morbidity rates are higher in children under two years of age. ${ }^{[7]}$ It is important to diagnose the disease early to prevent complications and to decrease mortality. ${ }^{[8]}$

Children are considered to be the most important carriers for the spread of influenza infection in the community. ${ }^{[9]}$ In addition, the lack of parents to continue their daily routines for the care of their children because of influenza infection leads to job losses. ${ }^{[9]}$ So, early diagnosis of influenza infections in children can contribute to both control the spread of the disease and reduce the negative socio-economic effects.

It has been reported that the parameters in the complete blood count can be used to predict the course and prognosis of many diseases in children and adults. ${ }^{[8,10-14]}$ Routine blood analyses are frequently performed in patients admitted to the hospital with complaints suggesting influenza infection. The parameters measured on the complete blood count can provide important clues about the severity of inflammation in patients. In this study, our aim is to compare the clinical status and inflammation findings of patients hospitalized for influenza infection by using findings of complete blood count parameters.

\section{MATERIAL AND METHOD}

This is retrospective case-control study, which included patients aged under 18 years old who applied to Necmettin Erbakan University Meram Medical Faculty Department of Pediatrics between October 2019 and March 2020 and had a positive rapid influenza test. The data of patients were obtained through the hospital medical record database. Patients with any chronic disease such as hematological diseases (leukemia, lymphoma, hemoglobinopathy, conditions causing bone marrow failure), chronic renal and liver disorders were not included in the study. Sociodemographic-clinical characteristics and complete blood count parameters of the patients were noted. The stages of forming the working group are shown in Figure 1.

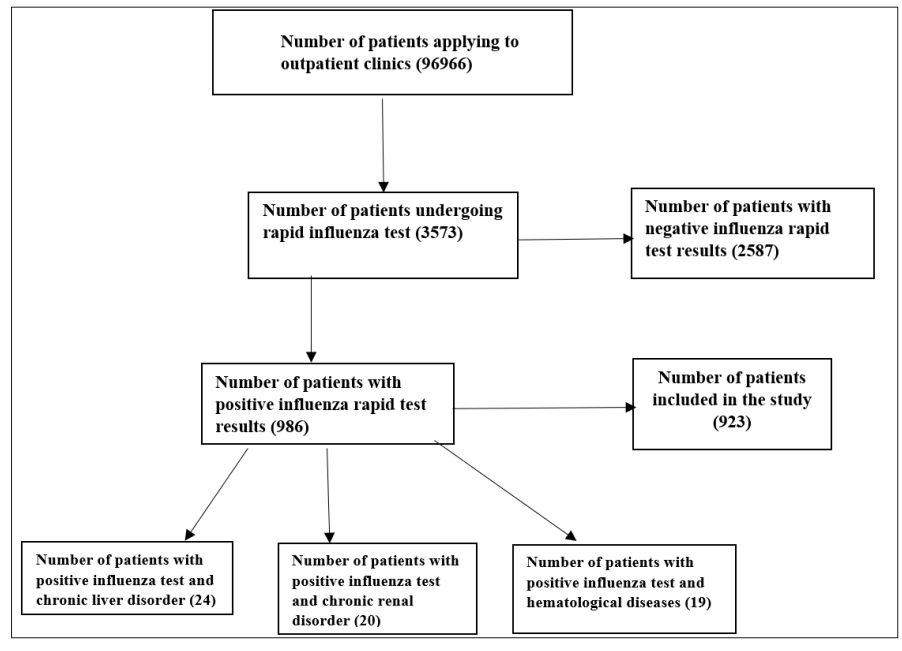

Figure 1. The creation of the study group

Nasal and nasopharyngeal swab samples from the patients were taken to Copan 606CS01PSwabs ${ }^{\mathrm{TM}}$ and Copan Universal Transport Medium ${ }^{\mathrm{TM}}$ viral transport medium (Copan, Italy). Samples that could not be delivered to the laboratory on the same day were stored at $4-8^{\circ} \mathrm{C}$ and delivered to the laboratory within 48 hours at the latest.

Patients were hospitalized if they met the criteria reported in the study of Jain et al. ${ }^{[15]}$ which were: body temperature above $39^{\circ} \mathrm{C}$, signs of severe lower respiratory tract infection (tachypnea, retraction, need for oxygen therapy), ill appearance and severe extrapulmonary complications. It was found that patients without these findings were followed up as outpatients.

This study was conducted with the approval of Necmettin Erbakan University Ethics Committee (Decision number: 2021/3136). In addition, all procedures were carried out in accordance with the Declaration of Helsinki and local laws and regulations.

\section{Statistical Analysis}

All statistical analysis was performed using SPSS for Windows 22.0. Shapiro-Wilk normality test and Q-Q plots were used to check the normality of the data. Mean platelet volume (MPV)/ platelet (PLT), PLT/lymphocyte, MPV/platecrit (PCT), PLT/ $\mathrm{PCT}$, neutrophil/lymphocyte ratios were analyzed by taking their logarithmic transformations since they showed a rightskewed distribution. Numerical variables were presented as mean \pm standard deviation if normally distributed, and as median (interquartile range: $25^{\text {th }}$ percentile- $75^{\text {th }}$ percentile) if not normally distributed. Other numerical variables such as age and hematological parameters were compared with independent samples t-test, Welch t-test or Mann-Whitney $U$ test. On the other side, categorical variables were described as counts (n) and percentages (\%), and were evaluated using Pearson chi-square, Yates continuity correction and also Fisher's exact test according to the expected frequency in each cell in the crosstabs. A p-value less than .05 was considered as statistically significant. 


\section{RESULTS}

A total of 923 children who were diagnosed with Influenza infection were included. 498 (54.0\%) of the patients were male and 425 (46.0\%) were female (Table 1). The median age was 45 months, with an age range of 19-72 months. The clinical and laboratory findings of patients with influenza $A$ and $B$ positive groups are given in Table 1. The median age (month) in the influenza B-positive group was significantly higher than in the influenza A-positive group. The gender distributions of the groups were similar.

The median MPV value in the influenza A-positive group was significantly higher than in influenza B-positive $(p<0.001)$. The median neutrophil value of the influenza A-positive group was significantly lower than in influenza B-positive $(p=0.008)$. The median monocyte value of the influenza A-positive group was significantly higher than influenza B-positive $(p=0.005)$. The median AST and ALT value of the

\begin{tabular}{lccc}
\hline \multicolumn{3}{l}{ Table 1. Demographic parameters of patients with influenza infection } \\
\hline Parameters & $\begin{array}{c}\text { Influenza } \\
\text { A-positive } \\
\text { (n=557) }\end{array}$ & $\begin{array}{c}\text { Influenza } \\
\text { B-positive } \\
\text { (n=366) }\end{array}$ & p-value \\
\hline Age (month) & $45(19-72)$ & $48(24-79)$ & 0.002 \\
Age Groups & $176(31.6)$ & $109(29.7)$ & 0.462 \\
0-24 age (month) & $217(38.9)$ & $131(35.7)$ & \\
25-60 age (month) & $144(25.8)$ & $111(30.3)$ & \\
61-144 age (month) & $20(3.5)$ & $15(4.1)$ & \\
$>144$ age (month) & $300(53.8)$ & $198(54.1)$ & 0.943 \\
Gender male & &
\end{tabular}

influenza A-positive group was significantly higher than influenza B-positive $(p=0.013, p=0.021$ respectively). There were no statistically significant differences for the other parameters between groups (Table 2).

The clinical symptoms of the patients with influenza A-positive and influenza B-positive are given in Table 3. While vomiting rate was significantly higher in the influenza A-positive group runny nose and sore throat rates were significantly lower in the influenza A-positive than in the influenza B-positive group. However, the other clinical symptoms showed no significantly difference between groups (Table 3-4).

\begin{tabular}{lcccc} 
Table 3. Clinical symptoms of the patients according to groups \\
Parameters & $\begin{array}{c}\text { Influenza } \\
\text { A-positive } \\
\text { (n=557) }\end{array}$ & $\begin{array}{c}\text { Influenza } \\
\text { B-positive } \\
\text { (n=366) }\end{array}$ & $\begin{array}{c}\text { Total } \\
\text { (n=923) }\end{array}$ & p-value \\
\hline Fever & $496(88.4)$ & $323(87.8)$ & $819(88.7)$ & 0.708 \\
Vomiting & $136(23.6)$ & $60(16.4)$ & $196(21.2)$ & 0.004 \\
Cough & $320(57.9)$ & $207(57.1)$ & $527(57.1)$ & 0.765 \\
Respiratory distress & $17(3)$ & $14(3.7)$ & $31(3.3)$ & 0.524 \\
Restlessness & $28(5)$ & $24(6.9)$ & $52(5.6)$ & 0.327 \\
Myalgia & $37(6.4)$ & $36(9.5)$ & $73(7.9)$ & 0.080 \\
Nasal flow & $202(37.5)$ & $174(48.7)$ & $376(40.7)$ & $<0.001$ \\
Diarrhea & $42(7.5)$ & $21(5.8)$ & $63(6.8)$ & 0.288 \\
Anorexia & $98(17)$ & $61(16.7)$ & $159(17.2)$ & 0.715 \\
Sore throat & $67(11.8)$ & $73(20.6)$ & $140(15.1)$ & $<0.001$ \\
Skin rash & $4(0.7)$ & $5(1.1)$ & $9(0.9)$ & 0.327 \\
Somnolence & $28(4.7)$ & $15(3.4)$ & $43(4.6)$ & 0.513 \\
Seizure & $22(3.6)$ & $19(4.5)$ & $41(4.4)$ & 0.370 \\
\hline
\end{tabular}

Table 2. Comprasion of laboratory parameters between groups of Influenza A and Influenza B

\begin{tabular}{|c|c|c|c|}
\hline Parameters & InfluenzaA-positive $(n=557)$ & Influenza B-positive $(n=366)$ & p-value \\
\hline White blood cell $\left(/ \mathrm{mm}^{3}\right)$ & $6680(4670-9300)$ & $6950(4825-9482)$ & 0.318 \\
\hline Mean platelet volume (MPV) & $9.5 \pm 1.1$ & $9.3 \pm 1.1$ & $<0.001$ \\
\hline Neutrophil $\left(/ \mathrm{mm}^{3}\right)$ & $3490(1930-5700)$ & $3650(2137-6160)$ & 0.008 \\
\hline Lymphocyte (/mm³) & $1910(1310-3170)$ & $1925(1317-3382)$ & 0.783 \\
\hline Hemoglobin $(\mathrm{g} / \mathrm{dL})$ & $12.07 \pm 1.4$ & $12.2 \pm 1.5$ & 0.364 \\
\hline Lymphocyte/Platelet $\left(\times 10^{5}\right) \#$ & $2.91 \pm 0.39$ & $2.91 \pm 0.29$ & 0.854 \\
\hline Platelet/PCT\# & $5.97 \pm 0.49$ & $6.04 \pm 0.92$ & 0.067 \\
\hline Neutrophil/lymphocyte\# & $0.19(-0.17-0.52)$ & $0.20(-0.03-0.49)$ & 0.359 \\
\hline Platelet/lymphocyte\# & $2.06 \pm 0.31$ & $2.07 \pm 0.29$ & 0.637 \\
\hline Monocyte/lymphocyte\# & $-0.56 \pm 0.32$ & $-0.58 \pm 0.31$ & 0.109 \\
\hline Monocyte/lymphocyte & $0.29(0.16-0.51)$ & $0.23(0.17-0.42)$ & 0.097 \\
\hline Urea $(\mathrm{mg} / \mathrm{dL})$ & $20(15-25)$ & $20(15-24)$ & 0.423 \\
\hline Creatinine $(\mathrm{mg} / \mathrm{dL})$ & $0.38(0.31-0.49)$ & $0.42(0.33-0.48)$ & 0.204 \\
\hline Fibrinojen $(\mathrm{mg} / \mathrm{dL})$ & $322.8 \pm 74.2$ & $305 \pm 69$ & 0.172 \\
\hline Creatinine phosphokinase (U/L) & $242.5(97.2-819.5)$ & $150(87-1342)$ & 0.882 \\
\hline $\mathrm{pH}$ & $7.37 \pm 0.07$ & $7.37 \pm 0.881$ & 0.080 \\
\hline $\mathrm{PCO}_{2}$ & $36.6 \pm 6.9$ & $36.1 \pm 6.4$ & 0.558 \\
\hline $\mathrm{HCO}_{3}$ & $20.9 \pm 4.1$ & $20.9 \pm 4.8$ & 0.868 \\
\hline Lactate & $1.9(1.3-2.5)$ & $1.9(1.5-2.4)$ & 0.335 \\
\hline
\end{tabular}


Table 4. Demographic and clinical parameters of the hospitalized groups

\begin{tabular}{lccc} 
Parameters & $\begin{array}{c}\text { Outpatient } \\
(\mathbf{n}=\mathbf{7 3 1})\end{array}$ & $\begin{array}{c}\text { Hospitalized } \\
(\mathbf{n}=\mathbf{1 9 2})\end{array}$ & p-value \\
\hline Age (month) & $48(24-74)$ & $36(15-60)$ & 0.001 \\
Age Groups & & & 0.003 \\
0-24 age (month) & $205(28)$ & $80(33)$ & \\
25-60 age (month) & $282(38.5)$ & $66(37.7)$ & \\
61-144 age (month) & $214(29.2)$ & $41(26)$ & \\
$>144$ age (month) & $30(4.1)$ & $5(3.3)$ & \\
Gender male & $394(53.9)$ & $104(53.5)$ & 0.947 \\
Use of oseltamivir & $726(99.3)$ & $192(100)$ & 0.517 \\
Bacteraemia & $11(1.5)$ & $62(32)$ & $<0.001$ \\
Chronic disease & & & $<0.001$ \\
None & $664(90.8)$ & $122(63.5)$ & \\
Familial Mediterranean Fever & $4(0.5)$ & $1(0.5)$ & \\
Cystic fibrosis & $5(0.7)$ & $5(2.6)$ & \\
Immune deficiency & $10(1.4)$ & $24(12.5)$ & \\
Neurological disease & $14(1.9)$ & $23(12.0)$ & \\
Cardiological disease & $12(1.6)$ & $6(3.1)$ & \\
Asthma & $7(1.0)$ & $5(2.6)$ & \\
Atopy & $9(1.2)$ & $2(1.0)$ & \\
Endocrine Disease & $4(0.5)$ & $2(1.0)$ & \\
Chronic lung disease & $2(0.3)$ & $2(1.0)$ & \\
Pediatric Intensive Care Support & $0(0)$ & $8(4.2)$ & $<0.001$ \\
\hline
\end{tabular}

Clinical and laboratory findings of outpatient and hospitalized patient groups are shown in Table 5. While the mean ages, mean hemoglobin concentrations (HGB) and mean creatinine values of the hospitalized patients were found to be significantly lower than the outpatients, the mean WBC count and the mean platecrit percentage (PCT) were found to be significantly higher in hospitalized patients. The other laboratory parameters showed no significantly difference between groups (Table 5).

\section{DISCUSSION}

Influenza has caused global and local epidemics many times since its first definition. Although mortality rates are not high in children, morbidity rates are high. Findings of influenza infection are similar to other viral diseases ${ }^{[8]}$ For this reason, the differential diagnosis of the disease is made with laboratory tests including rapid antigen tests, polymerase chain reaction $(P C R)$, viral culture, antibody determination, in addition to a detailed anamnesis and complete physical examination. ${ }^{[8]}$ But these laboratory studies are often expensive and timeconsuming. Hemogram test is performed in most of the children admitted to the hospital with symptoms of influenza infection.

Table 5. Laboratory parameters of Outpatients and Hospitalized Patients

\begin{tabular}{|c|c|c|c|}
\hline Parameters & Outpatient(n=731) & Hospitalized(n=192) & p-value \\
\hline Mean platelet volume(MPV) & $9.5 \pm 1.05$ & $9.65 \pm 1.25$ & 0.134 \\
\hline Neutrophil $\left(/ \mathrm{mm}^{3}\right)$ & $3360(1957-5232)$ & $3480(1795-6690)$ & 0.106 \\
\hline Lymphocyte $\left(/ \mathrm{mm}^{3}\right)$ & $1830(1307-2972)$ & $2190(1325-3845)$ & 0.072 \\
\hline Hemoglobin (g/dL) & $12.3 \pm 1.3$ & $11.6 \pm 1.5$ & $<0.001$ \\
\hline MPV/platelet $\left(\times 10^{5}\right) \#$ & $0.60(0.49-0.72)$ & $0.58(0.46-0.70)$ & 0.169 \\
\hline Lymphocyte/Platelet $\left(\times 10^{5}\right) \#$ & $2.9 \pm 0.37$ & $2.94 \pm 0.33$ & 0.310 \\
\hline Lymphocyte/monocyte\# & $0.53(0.31-0.76)$ & $0.62(0.33-0.82)$ & 0.061 \\
\hline MPV/PCT\# & $1.64 \pm 0.21$ & $1.61 \pm 0.19$ & 0.154 \\
\hline Platelet/PCT\# & $5.9 \pm 0.48$ & $6.01 \pm 0.12$ & 0.666 \\
\hline Neutrophil/lymphocyte\# & $0.21(-0.11-0.52)$ & $0.17(-0.13-0.52)$ & 0.919 \\
\hline Erythrocyte sedimentation rate $(\mathrm{mg} / \mathrm{h})$ & $15(10-25)$ & $15(8-26)$ & 0.931 \\
\hline C-reactive protein (mg/L) & $4.7(1.4-12.4)$ & $3.9(1.6-13.7)$ & 0.864 \\
\hline Aspartate aminotransferase (U/L) & $33(27.3-42)$ & $35(26.5-51)$ & 0.173 \\
\hline Alanine aminotransferase (U/L) & $12(9.6-18.2)$ & $14(10-22)$ & 0.080 \\
\hline Urea (mg/dL) & $20(16-25)$ & $20(14-25.2)$ & 0.433 \\
\hline Creatinine (mg/dL) & $0.42(0.33-0.50)$ & $0.36(0.30-0.46)$ & $<0.001$ \\
\hline Fibrinojen (mg/dL) & $316 \pm 80.4$ & $337.4 \pm 64.1$ & 0.615 \\
\hline Creatinine phosphokinase (U/L) & $135(80-470)$ & $285(172.5-1705.0)$ & 0.099 \\
\hline $\mathrm{pH}$ & $7.36 \pm 0.07$ & $7.37 \pm 0.07$ & 0.723 \\
\hline $\mathrm{PCO}_{2}$ & $40.2 \pm 9.3$ & $35.8 \pm 6.07$ & 0.039 \\
\hline $\mathrm{HCO}_{3}$ & $22.2 \pm 3.2$ & $20.6 \pm 4.2$ & 0.205 \\
\hline
\end{tabular}


In our study, the mean age of the influenza B positive group was found to be significantly higher than the influenza $A$. Studies have reported that influenza $B$ infection is more common in older children. ${ }^{[16-18]}$ The association between age and influenza $B$ infection may be related to the fact that the surface receptors necessary for the virus to infect host cells change with age.

In our study, $70.3 \%$ of the patients who were hospitalized due to influenza infection were found to be younger than five years old. Principi et al. ${ }^{[2]}$ reported that influenza infections had a more severe course in children under the age of two. In a study which conducted by Kondrich et al. ${ }^{[3]}$ it was reported that more than 800,000 children under the age of five are hospitalized every year due to influenza infection. In the study conducted by Moy et al. ${ }^{[9]}$ which children with influenza infection were investigated, it was reported that hospitalization rates under the age of five were $48-65 / 100000$, and this rate was higher in children under the age of six months.

In our study, it was found that $63 \%$ of the children hospitalized due to influenza infection did not have a chronic disease. Kondrich et al. ${ }^{[3]}$ reported that children with influenza infection may face severe clinical pictures even if they were previously healthy. Various studies have reported that influenza virus infection can cause respiratory, circulatory and neurological complications in healthy children. ${ }^{[2-4]}$ This may be due to the capacity of the microorganism to spread rapidly among children.

In our study, it was found that $45.2 \%$ of the children who had influenza infection had gastrointestinal system findings and showed significantly more vomiting symptoms in the influenza B positive group compared to the influenza A positive group. In a study, it was reported that $10-30 \%$ of children with influenza infection had gastrointestinal system findings ${ }^{[3]}$ Paules et al. ${ }^{[19]}$ reported in their study that influenza $B$ infection showed more gastrointestinal symptoms than influenza A infection.

In our study, no significant difference was found between the influenza $A$ and $B$ positive groups in terms of hospitalization and intensive care unit admission. Similar to clinical findings, no significant difference was found between influenza $A$ and B groups in terms of neutrophil/lymphocyte, platelet/ lymphocyte, monocyte/lymphocyte ratios. However, wbc and platecrit rate were significantly higher in the hospitalized group compared to the outpatients. In the study conducted by Fei et al. ${ }^{[7]}$ lymphocyte $x$ platelet multiplier and MPV (Mean platelet volume)/platelet ratios were found to be higher in children with influenza A infection compared to children with influenza symptoms but not influenza $A$. In the study of Zhu et al. ${ }^{[1]}$ lymphocyte, platelet count, lymphocyte/ monocyte ratio (LMR) and lymphocyte $x$ platelet multiplier were lower, neutrophil/lymphocyte ratio (NLR) and MPV/ platelet ratio were higher in children with influenza infection compared to the control group. These results show that there is no difference in terms of inflammation between influenza
$A$ and $B$ infections. Esposito et al ${ }^{[8]}$ reported that influenza $A$ infection had a more severe clinical manifestation compared to influenza $B$ infection. The fact that these parameters indicating inflammation are higher in hospitalized patients may be related to the correlation between the degree of clinical severity and inflammation.

Transaminase levels were found to be significantly higher in the influenza A group compared to the influenza B group in our study. However, when the mean values were taken into account, it was found that the transaminase values in both groups were within the normal reference ranges. In a review study conducted in the USA, it was reported that increased transaminases could be observed in children with influenza A infection. ${ }^{[20]}$

In our study, it was determined that the frequency of an underlying diseases in the hospitalized group was $36.5 \%$ for all inpatients and $93.3 \%$ of the outpatients received oseltamivir treatment, and the frequency of hospitalization in the intensive care unit was $4.2 \%$. In a study conducted in Australia, the frequency of an underlying disease in children hospitalized due to influenza infection was reported as $43 \%$, antiviral treatment use as $20.5 \%$, and the frequency of hospitalization in the intensive care unit as $8.5 \% .{ }^{[9]}$ In various studies, it has been reported that oseltemivir treatment provides the highest efficiency and decreases the contagiousness and morbidity of the disease when it is started in the first 24-48 hours of the disease. ${ }^{[7,20]}$ Making the diagnosis of influenza infection within minutes with the rapid antigen test and starting oseltamivir treatment early may have caused the frequency of hospitalizations to the intensive care unit to be low.

In our study, there was no significant difference between influenza $A$ and $B$ groups in terms of bacterial growth in blood culture. However, a significant increase in bacterial growth in blood culture was found in the hospitalized group compared to the outpatient group. No significant difference was found in the number of neutrophil and lymphocytes in inpatient and outpatient groups. Choe et al. ${ }^{[21]}$ reported that the frequency of bacteremia increased in patients hospitalized due to influenza virus infection. In addition, it has been reported that the decrease in the number of cells such as neutrophils and lymphocytes in the immune system during influenza virus infection may cause secondary bacterial infections. ${ }^{[7]}$ Tavares et al. reported that cytokines caused by influenza virus infection may lead to susceptibility to secondary bacterial infections by weakening their abilities such as chemotaxis, aggregation and activation without affecting the number of neutrophil and lymphocytes. ${ }^{[22]}$ Significantly higher rates of bacteremia in the group with influenza virus infection and requiring hospitalization may be associated with deterioration in the function of neutrophil and lymphocytes.

Our study had some limitations. The retrospective case control nature of the study, the absence of healthy children in the study group, and the rapid antigen test to diagnose influenza infection were the limitations of our study. 


\section{CONCLUSION}

There were no difference in the level of clinical severity between infleunza $A$ and $B$ subgroups and no significant difference was found in terms of hemogram parameters. Influenza virus infection is a disease that causes high morbidity in children. Rapid diagnosis and rapid initiation of treatment reduce morbidity and mortality rates. More randomized controlled studies are needed to investigate the effects of influenza infections in children.

\section{ETHICAL DECLARATIONS}

Ethics Committee Approval: This study was conducted with the approval of Necmettin Erbakan University Ethics Committee (Decision number: 2021/3136).

Informed Consent: All patients signed the free and informed consent form.

Referee Evaluation Process: Externally peer-reviewed. Conflict of Interest Statement: The authors have no conflicts of interest to declare.

Financial Disclosure: The authors declared that this study has received no financial support.

Author Contributions: All of the authors declare that they have all participated in the design, execution, and analysis of the paper, and that they have approved the final version.

\section{REFERENCES}

1. Zhu R, Chen C, Wang Q, et al. Routine blood parameters are helpful for early identification of influenza infection in children. BMC Infect Dis. 2020;20(1):864.

2. Principi N, Esposito S. Severe influenza in children: incidence and risk factors. Expert Rev Anti Infect Ther 2016;14(10):961-8.

3. Kondrich J, Rosenthal M. Influenza in children. Curr Opin Pediatr. 2017;29(3):297-302.

4. Paksu MS, Aslan K, Kendirli T, et al. Neuroinfluenza: evaluation of seasonal influenza associated severe neurological complications in children (a multicenter study). Child's Nerv. Syst. ChNS Off. J. Int. Soc. Pediatr. Neurosurg. 2018;34(2):335-47.

5. Uyeki TM, Bernstein HH, Bradley JS, et al. Clinical Practice Guidelines by the Infectious Diseases Society of America: 2018 Update on Diagnosis, Treatment, Chemoprophylaxis, and Institutional Outbreak Management of Seasonal Influenzaa. Clin. Infect. Dis. an Off. Publ. Infect. Dis. Soc. Am. 2019;68(6):895-902.

6. Yorulmaz A, Ağır MA, Arslan Ş. Benign Acute Childhood Myositis Associated with Influenza A (H1N1) Virus Infection: Evaluation of 22 Cases. J. Pediatr Infect Dis 2019;14(03):127-32.

7. Fei $Y$, Zhang $H$, Zhang $C$. The application of lymphocyte*platelet and mean platelet volume/platelet ratio in influenza $A$ infection in children. J. Clin Lab Anal 2019;33(9):e22995.

8. Esposito S, Molteni CG, Daleno C et al. Clinical and socioeconomic impact of different types and subtypes of seasonal influenza viruses in children during influenza seasons 2007/2008 and 2008/2009. BMC Infect Dis 2011;11:271.

9. Li-Kim-Moy J, Yin JK, Blyth CC, et al. Influenza hospitalizations in Australian children. Epidemiol Infect 2017;145(7):1451-60.

10. Chu SG, Becker RC, Berger PB, et al. Mean platelet volume as a predictor of cardiovascular risk: a systematic review and meta-analysis. J Thromb Haemost 2010;8(1):148-56.
11. Korniluk A, Koper-Lenkiewicz OM, Kamińska J, Kemona H, DymickaPiekarska V. Mean Platelet Volume (MPV): New Perspectives for an Old Marker in the Course and Prognosis of Inflammatory Conditions. Mediators Inflamm. 2019;2019:9213074.

12. Uzun N, Akıncı MA. Hemogram parameters in childhood anxiety disorders: Could anxiety disorders be related with inflammation? Med Hypotheses 2021;146:110440.

13. Akinci MA, Uzun N. Evaluation of hematological inflammatory markers in children and adolescents with attention deficit/hyperactivity disorder. Bratisl Lek Listy 2021;122(4):256-62.

14. Varman, Alkan, Alper S. Evaluation of neutrophil/lymphocyte ratio, platelet/lymphocyte ratio, mean platelet volume, and neutrophil/ monocyte ratio in patients with benign breast lesions. Bratisl Lek Listy 2021;122(7):489-92.

15. Jain VK, Rivera L, Zaman K, et al. Vaccine for prevention of mild and moderate-to-severe influenza in children. NEngl J Med 2013;369(26):248191.

16. Wada T, Morishima T, Okumura A et al. Differences in clinical manifestations of influenza-associated encephalopathy by age. Microbiol Immunol 2009;53(2):83-8.

17. Teutsch SM, Zurynski YA, Nunez C, et al. Ten Years of National Seasonal Surveillance for Severe Complications of Influenza in Australian Children. Pediatr. Infect Dis J 2021;40(3):191-8.

18. Han SB, Rhim J-W, Kang JH, Lee K-Y. Clinical features and outcomes of influenza by virus type/subtype/lineage in pediatric patients. Transl Pediatr 2021;10(1):54-63.

19. Paules C, Subbarao K. Influenza. Lancet (London, England) 2017;390(10095):697-708.

20. Livingston RA, Bernstein HH. Prevention of Influenza in Children. Infect. Dis Clin North Am 2015;29(4):597-615.

21. Choe YJ, Park S, Michelow IC. Co-seasonality and co-detection of respiratory viruses and bacteraemia in children: a retrospective analysis. Clin Microbiol Infect Off Publ Eur Soc Clin Microbiol Infect Dis 2020;26(12):1690.e5-1690.e8.

22. Tavares LP, Garcia CC, Machado MG, et al. CXCR1/2 Antagonism Is Protective during Influenza and Post-Influenza Pneumococcal Infection. Front Immunol 2017;8:1799. 